\title{
Dynamics of Land Use and Land Cover in the Kafta-Sheraro National Park, NW Ethiopia: Patterns, Causes and Management Implications
}

\author{
Zenebe Arafaine and Addisu Asefa* \\ Ethiopian Wildlife Conservation Authority, P.O. Box 356, Addis Ababa, Ethiopia \\ (*aa.mitiku@gmail.com).
}

\begin{abstract}
Kafta-Sheraro National Park (KSNP) is one of the most important protected areas in Ethiopia and provides a number of important ecological and hydrological benefits to the local people. However, the park is under immense pressure as a result of a rapidly increasing human population that resulted from a voluntary resettlement program launched by the government in 2003. Using satellite imageries taken in the years 2003, 2009 and 2015, this study examined patterns of changes in land use/cover throughout the park over a 12 year period (2003 to 2015), during which human population pressure is known to have increased over time and changes in government policies were taken place. The results showed that, over the period of 12 years, wood land experienced the most changeover the study period, with a loss of cover of $862.3 \mathrm{~km}^{2}$ (i.e. from $77.8 \%$ coverage of the total park area in 2003 to $38.0 \%$ in 2015 ) at annual rate of $79.3 \mathrm{~km}^{2}$ ). Conversely, the other land cover types showed increasing pattern, particularly, bush land and agricultural land were increasing at a rate of 44.96 and $18.90 \mathrm{~km}^{2}$ per year, respectively. Overall, the rate of land cover change was higher during the first period (2003 to 2009) compared with the second period (2009 to 2015) for all land use and land cover types, except grass land, suggesting that human impacts were higher following the resettlement program in 2003 and then slowed down following establishment of the park in 2007. The major causes of land cover change in the area were settlement and population expansion, cultivation, fire, mining and grazing. We suggest that better effective park protection systems should be in place to mitigate and restore habitats.
\end{abstract}

Keywords: Agricultural expansion, Habitat conversion, Human resettlement, Conservation, Remote sensing.

\section{INTRODUCTION}

Land use (e.g. grazing, agriculture, urban development, logging and mining) change is any modifications in physical, biological and/or chemical constituents of a given area attributable to land management regime, while change in land cover (e.g. cropland, forest, wetland, pasture, etc) means quantitative changes in the spatial extent (increase or decrease) of a given land cover type (Turner et al., 1995; Chen, 2002). Thus, studying changes in land cover and land use is becoming a central element to understanding local and global environmental changes and their driving forces (Nagendra, 2004). Understanding such dynamics can aid policy makers to give due attention and optimize their resource allocation either on the driver side through prevention or impact side through mitigation (Geist and Lambin, 2002; Eyob Teshome et al., 2011). 
Land cover change results from two important causes: natural and anthropogenic. Although natural events such as climate change, flood, bush-fire, and drought may modify land cover both locally and globally, the principal cause of alteration of land cover is associated with un-regulated human uses, including agricultural expansion, over-grazing, forest harvesting and urbanization (Vitosek et al., 1997; Nagendra, 2004). Currently, human induced modifications of land cover are advancing at a very high rate and greatly affecting most of the earth's surface due to rapid population growth rate and lack of policies related to socio-economic development and environmental protection or poor implementation of such policies (Turner et al., 1995; Chen, 2002; Lambin et al., 2003). Reports indicate that, since 1850s, $\sim 5$ million $\mathrm{km}^{2}$ grassland and $\sim 6$ million $\mathrm{km}^{2}$ woodland habitats worldwide (Lambin et al., 2003) and $\sim 3$ million $\mathrm{km}^{2}$ of woodland vegetation in dry land regions of Africa (Diress et al., 2010) have been converted to croplands. Such land use/land cover changes can have, directly and/or indirectly, long- and short-term impacts on the biophysical composition of the area, including soil loss and fluctuation in wetlands (Detenbeck, 1993), reduction in carbon storage (Kates et al., 1990), changes in biological composition and loss of biodiversity (Skole et al., 1994; Abate Shiferaw, 2011).The ultimate consequences are impairment of proper ecosystem functions and processes which, in turn, adversely affects- through loss of production and productivity, drought and erratic rainfall- the well-being (i.e. cultural and socio-economy) of local, as well far beyond, people who directly or indirectly rely on the services provided to them by the ecosystems (Millennium Ecosystem Assessment, 2007). Therefore, understanding current and historical land use and land cover changes, and the causes and consequences of such changes is important to develop or revise local, regional or national policies related to sustainable land use and socio-economic development (Geist and Lambin, 2002; Eyob Teshome et al., 2011).

At present, forest and woodland degradation and destruction in Ethiopia has been occurring at unprecedented rate due to the country's population unbridled population growth rate, which, with currently estimated at $2.6 \%$ per year, is among the highest in the world (World Bank, 2013).This rapid population growth is causing rapid and widespread conversion of natural habitats for human settlements, clearing for agriculture, logging, charcoal and firewood harvesting (Hurni, 1988; Campbell, 1991). Such natural habitat alterations in turn have resulted to serious biodiversity and environmental degradation in most parts of the country; ultimately causing recurrent droughts, erosion, erratic rainfall and reduction of agricultural products (Feoli et al., 
2002; Efrem Garedew et al., 2009; Belay Kassa et al., 2014). Currently, the highest rate of habitat change in Ethiopia has been recorded in the north western part of the country, where a reduction of woodlands from 79\% in 1985 to 35.1\% in 2014 has taken place(Belay Kassa et al., 2014; Zerihun Woldu and Csaplovicsa, 2014), which mainly is due to agricultural expansion, charcoal production, fuel wood collection, excessive wood harvest, grazing pressure and bush-fire (Mulugeta Lemenih et al., 2012; Zerihun Woldu and Csaplovicsa, 2014; Binyam Alemu et al., 2015). However, few attempts have been made to quantify the degree of this land use and land cover change and its impacts on biodiversity. One of the areas where such information has been lacking is the Kafta-Sheraro National Park (KSNP).

This study investigated land use and land cover change in the KSNP, by examining temporal changes in cover of vegetation types with a known increase in human population density and government policy changes. The present KSNP area was formerly known as "Shire Lowlands Wildlife Reserve" since 1960s to until 2007 when establishment of the park was proposed (KSNP, 2016). KSNP was officially established in 2014, although proper conservation activities were started in 2009, to conserve the most northernmost relict population of African Elephant (Loxodontaafricana) and several other wildlife species that are known to be rare and with unique populations in the country (Mekbeb Eshetu et al., 2002). For example, the only known populations of Roan antelope (Hippotragus equines), Red-fronted gazelle (Eudorcasrufifrons) and Demoiselle crane (Anthropoidesvirgo) for the country are from the area (Berihun Gebremedhin et al., 2011; EWCA, 2016). Furthermore, the area is the only source of perennial rivers, including Tekeze River and its tributaries, that provides year-round water for millions of people, as well their livestock, living in the surrounding and far beyond.

The specific objectives of this study were (i) to describe patterns of land use and land cover of the park at three points in time (2003, 2009 and 2015) and determine a time series of land cover changes in the park within this 12 year period; (ii) to explore the major causes of land use/cover change in the study area; and (iii) to assess the perceptions and attitudes of local communities and government officials towards these changes. As is typical of land conversion due to anthropogenic pressure through the increase in settlement, grazing, fire and agricultural expansion in the park (Dompka, 1996), we predicted that there would be a reduction in woodland areas and an increase in cultivation land, and grassland, shrubland and bare land cover types over the years. Further, given that the start of human population explosion in the area was since 2003, and that the area was 
upgraded to a national park status in 2007 , hence relatively a better protection has been in place since then (KSNP, 2016). We also predicted that the rate of land use and land cover change would be higher for the first period (2003-2009) than that of the second period (2009-2015).

\section{METHODOLOGY}

\subsection{The Study Area}

KSNP is situated in the north-western tip of Ethiopia in the Tigray Region, between $14^{\circ} 03^{\prime} 17^{\prime}$, and $14^{\circ} 27^{\prime} 52^{\prime \prime}$ ' north, and $36^{\circ} 41^{\prime} 43^{\prime \prime}$ ' and $37^{\circ} 40^{\prime} 31^{\prime \prime}$ ' east (Fig 1). The current spatial extent of the park is $\sim 2176 \mathrm{~km}^{2}$ between altitudes of $568 \mathrm{~m}$ a.s.1 to $1,163 \mathrm{~m}$ a.s.1. (KSNP, 2016). The park was initially proposed in 2007 mainly to conserve one of the relict populations of the African Elephant found in the area and other co-occurring biodiversity and ecosystems (KSNP, 2016). Although its management office was established and became functional in 2009, legal status for the park was secured only in 2014 and it is currently managed under the auspices of the Ethiopian Wildlife Conservation Authority (FDRE, 2014; KSNP, 2016).

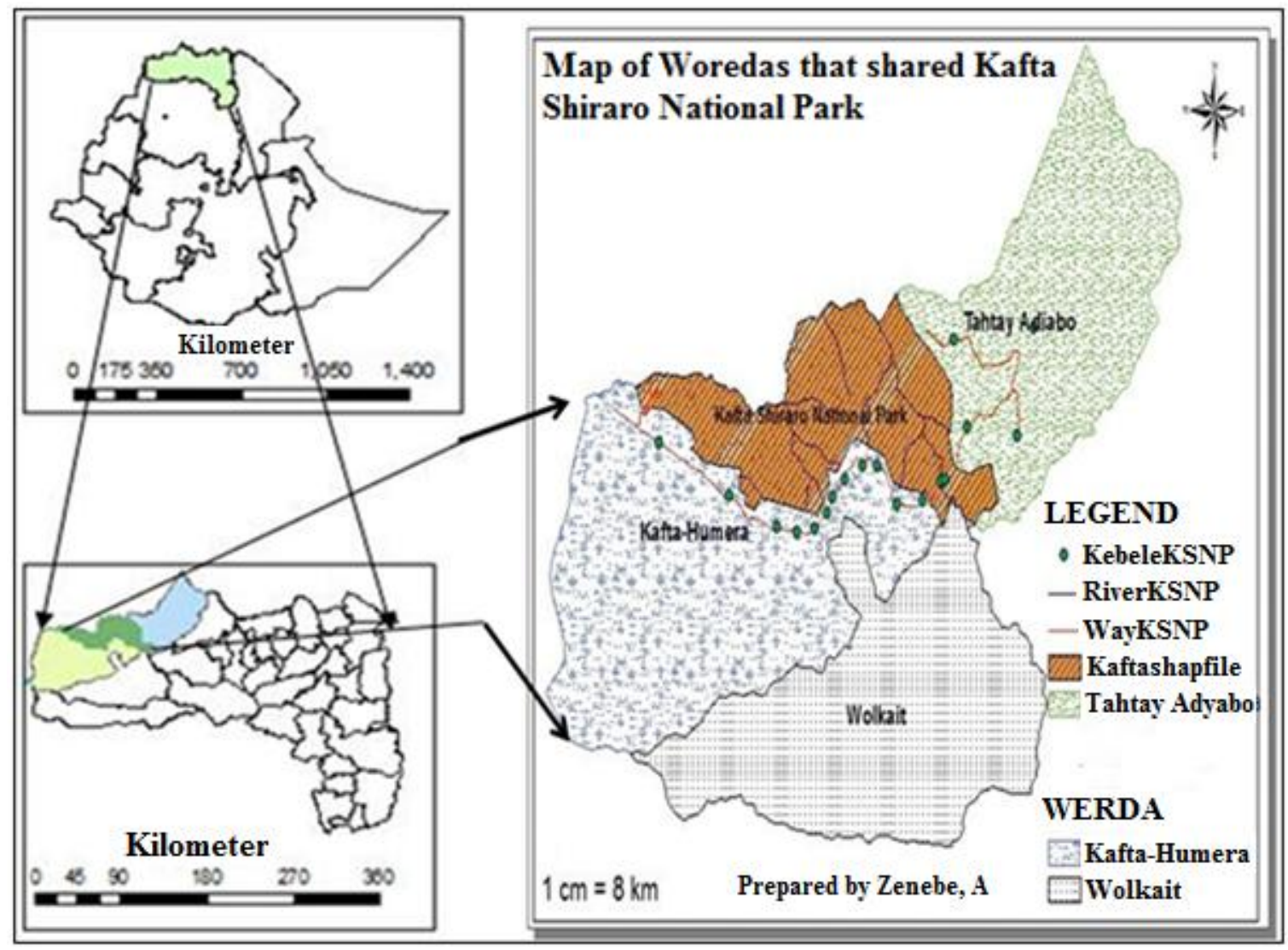

Figure 1. Map of the study area. 
The Kafta-Sheraro area is characterized by a mono-modal type of rainfall regime, occurring between May and early September although small rains occasionally occur from late September through November. With an annual average precipitation of about $600 \mathrm{~mm}$, the area receives low rainfall amounts compared to the surrounding highlands (Mekbeb Eshetu et al., 2002). Overall, average monthly temperature in the area varies between $18.2^{\circ} \mathrm{C}$ to $37.5^{\circ} \mathrm{C}$, with the warmest period being from April through May while the coldest from July through August (Addisu Asefa et al., 2016 unpublished data). KSNP is one of the most important conservation areas in Ethiopia; it hosts several conservation concern and economically important faunal and floral species (EWNHS, 2001; Mekbeb Eshetu et al., 2002).

Vegetation in KSNP is dominated by Acacia-commiphora and Combretum-terminalia woodlands that contain several economically important tree species, such as Boswellia papyrifera that provide the widely known and traded frankincense gum (Wualem Tadesse et al., 2007). The Park is home to many ungulates, predators and other wild animal species. The presence of some mega wild animals such as the African elephant, Roan Antelope and Red-fronted Gazelle, and several migratory bird species including the only known population of Demoisselcrane in the country make the park and its environs a significant conservation site for the national as well as international communities.

Historically, the KSNP area had been inhabited by the Kunama people who used to rely for livelihood mainly on livestock husbandry and harvesting of wild flora and fauna (Mekbeb Eshetu et al., 2002). As such, the Kafta-Sheraro region as a whole had been very limited as the region was under the control of the current "Tigray People Liberation Front" since early 1960s to 1990s where a frequent armed-war was occurring between them and the then Ethiopian government [or the "Dergie regime", 1974-1993]. As a result, socio-economic activities in the area and human disturbances to the environment were at low level until late 1990s, after which the area has been rapidly populated as result of the volunteer resettlement program launched by the regional government in late 2003 (KSNP, 2016). Human population size in and around the KSNP area was estimated at 21,575 people in 2003; 37,775 in 2009; and 64,000 in 2015 (KSNP, 2016). On average $\sim 520,000-530,000$ heads of livestock use the park for grazing every year (KSNP, 2016). In addition to the rapidly increasing trend of settlements and human and livestock populations in the area, cultivation land expansion, traditional gold mining, extraction of frankincense gum and wildlife poaching are among the major threats to the park (Berihun Gebremedhin et al., 2011). 


\subsection{Materials and Methods}

We used satellite images and ground truthing points collected during the study period to classify land use and land cover types of the park. Information on land cover change driving forces, and perceptions and attitudes of people towards these changes was obtained through informal interviews and focus group discussions made with key informants from among local communities and relevant government officials.

\subsubsection{Satellite Image Acquisition and Preparation}

Three types of satellite images, all with spatial resolution of $30 \mathrm{~m}$ and three band combinations, were downloaded from the USGS online data provision interface (http://edc.usgs.gov/products/satellite/raster.html) and used for the study: Land Sat5 (acquisition date: 10/06/2003), Land Sat7 (18/06/2009) and Land Sat8 (20/06/2015) for the year 2003, 2009 and 2015, respectively). A voluntary resettlement of people from the other parts of Tigray region to areas around the park was undertaken from 2003 to 2005 (Binyam Alemu et al., 2015; KSNP, 2016). Later, to abate human threats posed on natural resources of the area which were brought about by increasing demand of arable land by the resettled people, establishment of KSNP was proposed in 2007 and park management and protection started in 2009. Therefore, the study years of 2003, 2009 and 2015 were purposively selected to assess the land use and land cover changes after resettlement program (2003 to 2009 or 2003 to 2015) and after the start of park protection (2009 to 2015). The month of June was selected for each study year since this month is the switch on/off time for low lands, which shows a clear spectral reflectance on the different land use/cover (FAO, 2005). Prior to analyses the satellite images were preprocessed in order to enhance efficiency, harmonize data and to reduce errors (Jensen, 1996). Firstly, the satellite images were stacked to produce a multispectral image from each of the panchromatic bands provided per image. Secondly, the satellite images were geo-rectified using the geometric registration strategy, where images are rectified with ground features to reduce positional inaccuracies which stem from geometric instability of the satellites during the data acquisition (Jensen, 1996). And finally, each of the stacked satellite images was clipped to polygon shape file of the KSNP in ERDAS Imagine 9.2 software.

\subsubsection{Image Classification}

Unsupervised classification method was applied first to identify land cover types. The outputs from this unsupervised classification were checked against local knowledge of the study area and 
easily distinguishable land cover of the study area from high-resolution Google earth. Accordingly, five and cover types were defined and used for further analyses: woodland, bush land/shrub land, grassland, agricultural (cultivation) land and bare land. Then ground truthing points were taken at 300 randomly generated points in the study area. This number of points is well above the recommended number for the Maximum Likelihood Classifier Technique, which is a minimum of 250 points for total study area (Eyob Teshome et al., 2011). Ground truthing points were located by hand-held GPS $72 \mathrm{H}$ and the vegetation type, altitude, slope and aspect were recorded. These ground-truthing points were used to make the training areas around which polygons for each class were drawn to define the digital signature. Finally, a supervised classification method was applied using the signatures defined for the training areas (LEICA Geosystems, 2003). Supervised classifications of all images were carried out using the Maximum Likelihood Classifier Technique in ERDAS Imagine software version 9.2. This method is the most preferred as it takes into account the most variables by using a covariance matrix.

\subsubsection{Accuracy Assessment}

Once the images were classified by the supervised method, then a further 300 random points were generated and data collected as above, in order to verify and assess the accuracy of the supervised classification. Accuracy was determined by superimposing the points on the classified image in ERDAS Imagine software and obtaining the kappa coefficient which expresses the proportion of reduced error as generated by the classification process compared with the error of a completely random classification; hence a value of one indicates an accuracy of $100 \%$ or zero error (LEICA Geosystems, 2003). Images were reclassified by altering the training areas, until the accuracy met the minimum requirement of $80 \%$ as set by Anderson et al. (1976).

\subsubsection{Land Cover Change}

The three images were compared to detect land cover change in two phases, 2003-2009 and 2009-2015. Classified images were compared using the post classification image comparison technique (LEICA Geosystems, 2003) in ERDAS Imagine. This technique creates one image based on the difference of the two comparative images from each year, which provides a summary table of the overall changes per class; positive values denote an increase whereas negative values

imply a decrease. Rate of conversion for each land cover type over each of the two periods of years was computed by dividing cover change $\left[\right.$ in $\left.\mathrm{km}^{2}\right]$ of a particular class by the number of years encompassed in each period (Amanuel and Mulugeta Lemenih, 2014). 


\subsubsection{Causes of Land Cover Change, and Community's Perceptions and Attitudes}

Field observations were made in 2015 to record information on current land use types and major threats in the park. Further, in order to have a better understanding on the temporal patterns (type and extent) of the causes of land use and land cover changes in the park, and on the perceptions and attitudes of local communities and government authorities towards these changes, we also conducted a total of 18 different focus group discussions (FGDs) in June/July 2016. One FGD was conducted with each of 12 villages' residents, and 2 districts' and 2 zones' and 2 regional authority officials and experts. Each FGD consisted of 10-20 participants and discussions lasted between 2-4 hours. Open-ended, semi-structured questions were prepared in English language for the discussion and discussions were made in local languages (Tigrigna and Amharic), led by an expert who speaks both languages. The questions were simple and straight forward, and included whether the discussants knew the past and present nature/types of key threats to the park; ii) major changes occurring in land use and land cover in the park in the last three to four decades; iii) the direct and indirect causes of land cover type; and iv) what their attitudes were towards the changes and suggestions for future sustainable conservation of the park and development of their livelihoods.

\section{RESULTS}

\subsection{Land Use and Land Cover Classification}

Land cover classes in the study area for the each year of 2003, 2009 and 2015 were shown in figure 2a-c. The maps clearly show persistent dominance of woodland throughout the study periods which covers 38-78 \% of the total area and bare land being the rarest land cover class, covering a mere $0.01-1.30 \%$ over the study period (Table 1). Classification accuracy assessment made, based on the 2015 image, showed that overall accuracy was 94\%. Of the land cover classes bare ground (100\% accuracy) appeared to be the most accurately classified, followed by wood land grass land (both 95\%), cultivation land (89\%) and bush/shrubland (93\%). These results suggest that our land cover classification has acceptable level of accuracy; thus valid conclusions could be made.

\subsection{Land Use and Land Cover Changes}

Results showed that all land cover classes exhibited some degree of change over the study period (Table 1). Woodland changed the most (a reduction from $77.8 \%$ of total park coverage in 2003 to $38.0 \%$ in 2015), followed by bush/shrub land (an increase from 5.7\% in 2003 to $30.6 \%$ in 2015). 


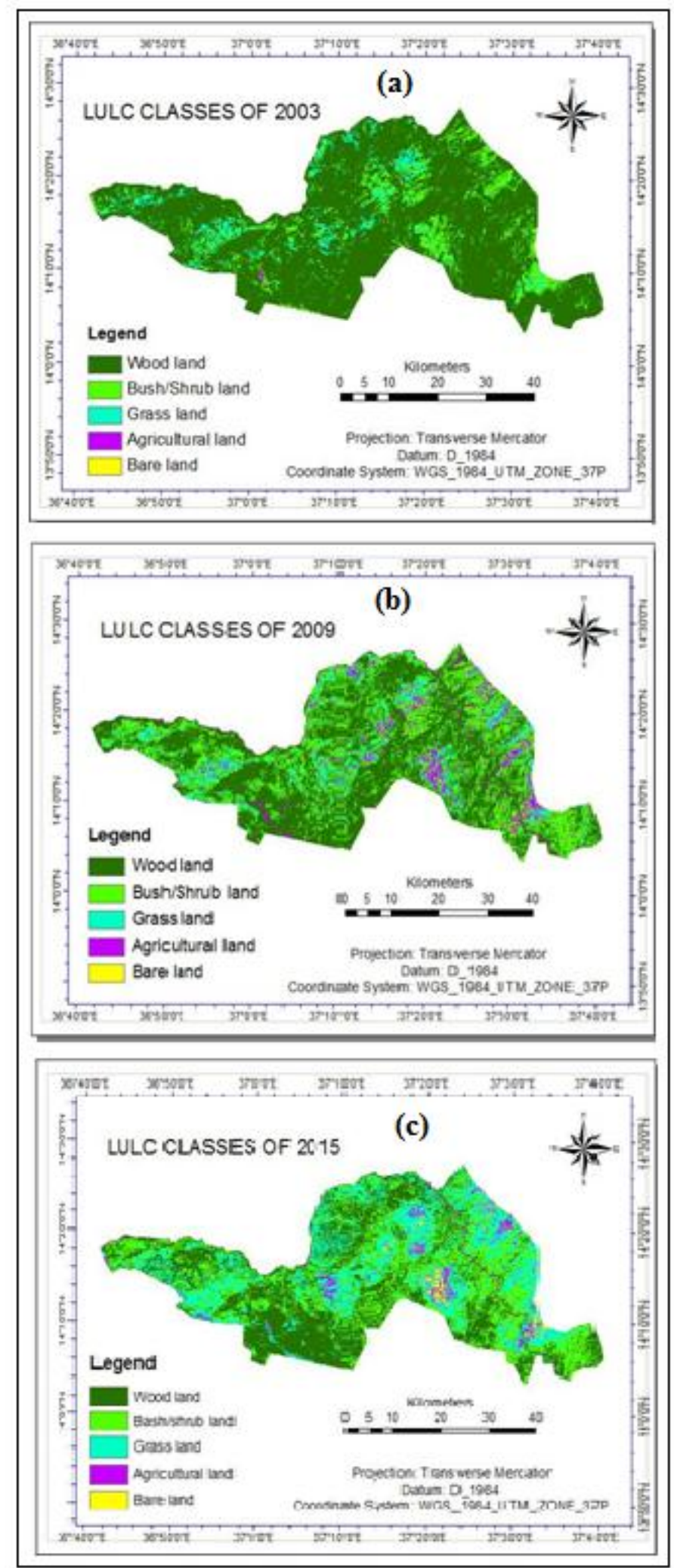

Figure 2. Land cover and land use classes of KSNP in the years 2003 (a), 2009 (b) and 2015 (c). 
Table 1. Total area and percentage cover of each land cover class in each of the three years used in this study.

\begin{tabular}{|lllllll|}
\hline \multirow{2}{*}{ aand cover } & \multicolumn{2}{c}{ 2003 } & \multicolumn{2}{c|}{ 2009 } & \multicolumn{2}{c|}{2015} \\
\cline { 2 - 7 } & Area $\left.\mathbf{( k m}^{2}\right)$ & Percent & Area $\left(\mathbf{k m}^{2}\right)$ & Percent & Area $\left(\mathbf{k m}^{2}\right)$ & Percent \\
\hline Wood land & 1683.9 & 77.813 & 1153.5 & 53.302 & 821.58 & 37.97 \\
\hline Shrub land & 122.7 & 5.6699 & 692.32 & 31.992 & 662.17 & 30.60 \\
\hline Grass land & 354.41 & 16.377 & 176.47 & 8.1548 & 581.22 & 26.86 \\
\hline $\begin{array}{l}\text { Agricultural } \\
\text { land }\end{array}$ & 2.86 & 0.132 & 138.1 & 6.3817 & 70.24 & 3.25 \\
\hline Bare land & 0.16 & 0.0073 & 3.66 & 0.1691 & 28.81 & 1.33 \\
\hline Total & 2164 & 100 & 2164 & 100 & 2164 & 100 \\
\hline
\end{tabular}

Table 2. Change in land cover in Kafta-Sheraro National Park in each time period interval; changes expressed in percentage and rate (change per year).

\begin{tabular}{|c|c|c|c|c|c|c|c|c|c|}
\hline \multirow{2}{*}{$\begin{array}{l}\text { Land } \\
\text { cover }\end{array}$} & \multicolumn{3}{|c|}{2003 to 2009} & \multicolumn{3}{|c|}{2009 to 2015} & \multicolumn{3}{|c|}{2003 to 2015} \\
\hline & $\begin{array}{l}\text { Total } \\
\text { area } \\
\text { change } \\
\left(\mathrm{km}^{2}\right)\end{array}$ & $\begin{array}{l}\text { Percent } \\
\text { change }\end{array}$ & $\begin{array}{l}\text { Change } \\
\text { per year } \\
\left(\mathrm{km}^{2}\right)\end{array}$ & $\begin{array}{l}\text { Total } \\
\text { area } \\
\text { change } \\
\left(\mathrm{km}^{2}\right)\end{array}$ & $\begin{array}{l}\text { Percent } \\
\text { change }\end{array}$ & $\begin{array}{l}\text { Change } \\
\text { per year } \\
\left(\mathrm{km}^{2}\right)\end{array}$ & $\begin{array}{l}\text { Total } \\
\text { area } \\
\text { change } \\
\left(\mathrm{km}^{2}\right)\end{array}$ & $\begin{array}{l}\text { Percent } \\
\text { change }\end{array}$ & $\begin{array}{l}\text { Change } \\
\text { per year } \\
\left(\mathrm{km}^{2}\right)\end{array}$ \\
\hline Wood land & -530.43 & -31.50 & -88.40 & -331.89 & -28.77 & -55.32 & -862.32 & -51.21 & -71.86 \\
\hline Shrub land & 569.62 & 464.24 & 94.94 & -30.14 & -4.35 & -5.02 & 539.47 & 439.67 & 44.96 \\
\hline Grass land & -177.94 & -50.21 & -29.66 & 404.75 & 229.36 & 67.46 & 226.81 & 64.00 & 18.90 \\
\hline $\begin{array}{l}\text { Cultivatio } \\
\mathrm{n} \text { land }\end{array}$ & 135.24 & 4728.67 & 22.54 & -67.86 & -49.14 & -11.31 & 67.38 & 2355.94 & 5.62 \\
\hline Bare land & 3.50 & 2187.50 & 0.58 & 25.14 & 687.16 & 4.19 & 28.65 & 17906.25 & 2.39 \\
\hline
\end{tabular}

When these two periods (i.e. 2003 to 2009, and 2009 to 2015) were considered separately, during both periods, woodland showed a decrease in total area while bare ground showed an increase (Table 1). Grass land showed a decrease in area coverage during the first period and an increase during the second period. Although bush land and agricultural land showed an increase in the total areas during the first period, both showed a little decrease in the second period (Tables1 and 2). While, proportionally similar percent changes were found for woodlands (2003 to 2009, $31.50 \%$ vs 2009 to $2015,28.77 \%$ ) during the two periods, larger changes were recorded between 2003 and 2009 for bush land, agricultural land and bare land compared to the period between 2009 and 2015. Grass land was the only land cover type that showed greater change during the second period (-50.21\% vs 229.36\%) (Table 2).

The annual rate of change was found to be faster for woodlands, bush land and agriculture 
in the first period and for grass land and bare ground in the second period (Table 2). This rate of land cover loss of the woodland habitat was 103.2and66.4 $\mathrm{km}^{2}$ per year during the first and the second periods, respectively; whereas, bush land and agriculture showed an increase of 71.6 and $22.5 \mathrm{~km}^{2}$ per year during the first period and a decrease of 5.7 and $13.6 \mathrm{~km}^{2}$ per year in second period, respectively (Table 2). Nearly, $60 \%$ of the study area remained unchanged throughout the study period, of which $38 \%$ of the unchanged habitat was woodland.

As shown in table 3 of land use and land cover change matrix, notable transformations found during the first period were changes from wood land $\left(560 \mathrm{~km}^{2}\right)$ and grass lands $\left(129 \mathrm{~km}^{2}\right)$ to shrub land and from grass land $\left(103 \mathrm{~km}^{2}\right)$ to cultivation land. Change of wood lands to shrub land $\left(342 \mathrm{~km}^{2}\right.$ ) was also high during the second period, but $279 \mathrm{~km}^{2}$ of shrub land cover was changed to grass land (Table 3).

Table 3. Matrix of land use and land cover change (in $\mathrm{km}^{2}$ ) between 2003 to 2009 and 2009 to 2015 in the KSNP.

\begin{tabular}{|c|c|c|c|c|c|c|}
\hline \multicolumn{7}{|c|}{ (a) 2003 to 2009} \\
\hline & & \multicolumn{5}{|c|}{$2009 \mathrm{LU} / \mathrm{LC}$ type } \\
\hline & & $\begin{array}{l}\text { Wood } \\
\text { land }\end{array}$ & $\begin{array}{l}\text { Shrub } \\
\text { land }\end{array}$ & $\begin{array}{l}\text { Grass } \\
\text { land }\end{array}$ & $\begin{array}{l}\text { Agricultural } \\
\text { land }\end{array}$ & $\begin{array}{l}\text { Bare } \\
\text { land }\end{array}$ \\
\hline \multirow{5}{*}{ 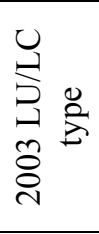 } & Wood land & 1032.17 & 560.54 & 64.33 & 26.86 & 0.01 \\
\hline & Shrub land & 114.00 & 2.24 & 0.00 & 6.46 & 0.00 \\
\hline & Grass land & 6.10 & 129.53 & 112.14 & 103.13 & 3.51 \\
\hline & Cultivation land & 1.20 & 0.01 & 1.65 & 1.65 & 0.01 \\
\hline & Bare land & 0.00 & 0.00 & 0.00 & 0.01 & 0.15 \\
\hline \multicolumn{7}{|c|}{ (b) 2009 to 2015} \\
\hline & & \multicolumn{5}{|c|}{2015 LU/LC type } \\
\hline \multirow{5}{*}{ 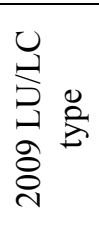 } & Wood land & 692.32 & 342.44 & 114.33 & 4.39 & 0.00 \\
\hline & Shrub land & 108.33 & 292.40 & 279.36 & 11.93 & 0.31 \\
\hline & Grass land & 7.27 & 22.97 & 120.42 & 17.76 & 1.66 \\
\hline & Agricultural land & 7.27 & 4.37 & 66.96 & 35.76 & 23.74 \\
\hline & Bare land & 0.00 & 0.00 & 0.16 & 0.40 & 3.10 \\
\hline
\end{tabular}

\subsection{Causes of Land Cover Change, and Community's Perceptions and Attitudes}

According to the discussants, the Kafta-Sheraro region represents one of the few areas in the northern Ethiopia where vast fertile arable land and economically important natural resources (e.g. gold, marble, natural gum/resign etc.) are found. However, exploitation of these resources began recently following the voluntary resettlement that was launched in the early 2000s when peace and stability was secured in the region after some decades of civil war in the region. This uncontrolled 
flow of people to the area and unregulated land use practices has led to ever-increasing conservation incompatible anthropogenic actions, such as expansion of settlement and cultivation land, unregulated bush-fire, excessive wood harvest, gold mining and over grazing, ultimately causing a rapid change in land use and land cover types. In addition to these human-induced drivers, however, the key informants also indicated that natural drivers such as climate change and erratic rainfall were also reported to contributing to land cover conversion in study area. In general, the FGDs' participants explained that the current trend of land use/cover changes in the KSNP is undesirable and would have adverse impacts on the biodiversity, ecosystem and human well-being. Accordingly, they suggested that integrative sustainable conservation of the park and development of livelihoods of the local community should be in place to reduce the unregulated natural resource exploitation in the par.

\section{DISCUSSION}

\subsection{Patterns and Causes of Land Use and Land Cover Changes}

As predicted, the present study confirms that the KSNP is undergoing major land transformation which appeared to be accelerated during 2003 to 2009 than recent times (2009-2015). These results may suggest that increasing human population following the resettlement program in 2003 and coupled to the lack of natural resources protection system during then have caused rapid land transformation during the first period (2003 to 2009). However, the relatively better protection in place following the declaration of establishment of the park in 2007 might have slowed down the rate of change during the second period (2009 to 2015). Thus, this study has not only shown patterns of land use/land cover change in the study area, but also how changes in regional and/or national social and environmental development policies impact conservation and sustainable use of natural resources.

The study of patterns in land cover and land use changes and the underlying causes can provide important information particularly in the field of conservation management, as it helps identify areas in need of attention and their underlying threats (Geist and Lambin, 2002; Nagendra et al., 2004; Eyob Teshome et al., 2011). The KSNP is an area of biological and hydrological importance, but is currently facing multi-faceted threats due to human encroachment, which potentially leads to significant land transformation and impair proper ecosystem processes and functions (Eyob Teshome et al., 2011; Binyam Alemu et al., 2015; KSNP, 2016). Results of the 
present study indicated that the different land cover types showed three various patterns of change during the two time periods. While woodland cover was decreasing and bare land was increasing during both periods, agricultural land and bush land were increasing in the first period but were declining in the second period. However, grass land decreased during the first period and increased then after. These patterns may indicate that the different land cover types have been exposed to varying types and levels of land use types and/or threat factors - that individually or interactively cause these changes - during the two periods. For example, the beginning of cultivation in 2003 might have resulted to heavy transformation of grassland followed by woodland land cover types, while increased grazing and fire in these land cover types might have favored expansion of bush land during the first period nearly $560 \mathrm{~km}^{2}$ (33\% of original cover) and $130 \mathrm{~km}^{2}(32 \%)$ of woodland and grassland, respectively, being converted to bushland during this time interval (Table 2) (see Endawek Wondim et al., 2014 unpublished data). However, abandonment of cultivation land from certain areas, by relocating some of the farmers cultivating inside the park to elsewhere outside the park in 2009 (KSNP, 2016), might have led to decrease in cultivation land during the second period. Whereas, overstocking of livestock and frequent fire burning of the woodlands and bush lands might have induced the expansion of grassland and bare land with the expense of the former land cover types during the second period (2009 to 2015).Such transformation of specific land cover types including shrubland or wood land into grasslands and bare ground is widely recognized as a consequence of human-induced pressure (Dompka, 1996; Geist et al., 2002; Feoli et al., 2002; Eyob Teshome et al., 2011).

As discussed above, the primary cause of the land use and land cover changes observed in the KSNP is underpinned by increasing human population size in and around the KSNP area, which has been shown an increase of $\sim 18 \%$ between the years 2003 and 2009, and 69\% between 2009 and 2015 (Endawek Wondim et al., 2014 unpublished data; KSNP, 2016). These reports have also indicated that annual population growth rate in the area to be five times $(\sim 13 \%)$ higher than the average annual growth rates both in the Tigray regional state $(\sim 2.5 \%)$ and in the country $(2.6 \%)$ (see CSA, 2007; World Bank, 2013). This rapidly growing human population in the area has been increased the demand for, in addition to cultivation land, various forms of natural resources use. For example, on average $\sim 520,000-530,000$ heads of livestock from the surrounding areas use the park for grazing every year (KSNP, 2016). In order to induce the growth of new grasses for their livestock, people deliberately catch bush fires, burning over $60 \%$ of the park area each year 
(KSNP, 2016). Similarly, although started recently (six 6 years ago), traditional gold mining is becoming one rapidly growing major threat to KSNP. Endawek Wondim et al. (2014, unpublished data) have reported $\sim 10,000$ gold mining pits each of which have 20-35 m depth and width along $179 \mathrm{~km}$ long transect surveyed. Given these facts, it is therefore, possible to suggest that much of the habitat transformation observed in the KSNP is due to the human-induced activities. Several studies conducted in different areas of Ethiopia (e.g. Diress et al., 2010; Mengistu Gebremariam and Fassil Kibebew, 2010; Abate Shiferaw, 2011; Messay Mulugeta, 2011; Mulugeta Lemenih et al., 2012) and elsewhere globally (Geist and Lambin, 2002; Lambin et al., 2003) have also been highlighted the disastrous consequences on biodiversity, ecosystem and human well-beings of increased human population in and around such biologically and ecologically important protected areas.

\subsection{Implications of the Study}

Results of the present study have shown that considerable land use and land cover changes have been occurred in the KSNP over the period of 12 years studied. Although increasing human population and associated livelihood activities are the proximate causes of the changes, lack of commitment to implement land use policy (as was reflected during the 2003 resettlement program) and poor law enforcement activities (observed since the establishment of the park) are the main underlying causes for the increased threat and thus land use and land cover changes in the park. This implies, from biodiversity conservation perspective, that unless a proper and better park management and land use strategies are in place, it is likely to observe expansion of existing settlements and socio-economic activities. This, in turn, will, lead to continued increasing land conversion. On the other hand, continued pressure on the park does not only adversely affect biodiversity, but also severely affects the vital ecosystem services they provide to the local community and their well-beings (Geist and Lambin, 2002; Millennium Ecosystem Assessment, 2007).

\section{CONCLUSION AND RECOMMNEDATIONS}

Results of the present study showed that considerable land use and land cover changes have been occurred in the KSNP over the period of 12 years studied. The major direct causes of land cover change in the area were settlement and population expansion, cultivation, fire, mining and grazing. In general, although such changes could be attributed to natural factors as climate change, erratic 
rainfall or grazing/browsing of wild herbivores (Duncan et al., 1999), our results support the idea that much of this transformation is due to human-induced activities. Therefore, the following three management actions should be taken to mitigate the adverse impacts that these land use/cover changes in the KSNP would have on the biodiversity, ecosystem and human well-being. Firstly, routine law-enforcement activities that involve local communities should be strengthened to mitigate overall human pressures to the park. Secondly, certain types of natural resources by local communities that potentially cause less harm to the park, such as limited livestock grazing during shortage of forage, fuel wood collection, gum collection and gold mining, should be allowed under regulated and controlled manner. And thirdly, people living and/or cultivating inside the park boundary should be relocated while providing them with alternative land from outside the park. Moreover, in order to quantify the impacts of human-induced threats on the ecosystem of the park so as to develop predictive and preventative models, we also suggest that further in depth studies to be undertaken on the spatiotemporal effects of such human activities on (1) vegetation diversity, population structure and regeneration, (2) carbon stocking rate of the different land cover/land use types, and (3) soil and water physiochemical properties. These studies can be used to assist park management to identify key areas currently under rapid transformation, so that intervention can occur to halt or slow down the present level of land change.

\section{ACKNOWLEDGMENTS}

All the Kafta-Sheraro National Park staff, local communities and government officials who helped us during the field data collection and provided information are duly acknowledged. We also would like to express our sincere thanks the Ethiopian Wildlife Conservation Authority and Kafta-Sheraro National Park for the financial and material support and research permit provided.

\section{CONFLICT OF INTEREST}

There are no conflicts of interests.

\section{REFERENCE}

Abate Shiferaw. 2011. Evaluating the land use and land cover dynamics in Borena woreda of south Wollo highlands, Ethiopia. Journal of sustainable development in Africa, 13: 267-284. 
Addisu Asefa, Gebremeskel Gizaw, Teshale Atsibah, Rezenom Almaw and Kinfe Welay. 2016. Kakafta-Sheraro National Park in the NW Ethiopia: Exceptional Resource Values, Principal Ecosystem Components and Human-Induced Threats. Report, EWCA Addis Ababa, 27p (unpubl.).

Amanuel, A \& Mulugeta Lemenih. 2014. Detecting and quantifying land use/ land cover dynamics in Nadda Asendabo watershed, south western Ethiopia. International Journal of Environmental Sciences, 3(1): 45-50.

Anderson, J.R., Hardy, E.E., Roach, J.T \& Witmer, R. E. 1976. A land use and land cover classification system for use with remote sensor data: Geological survey professional paper no. 964. United States Government Printing Office, Washington D.C.

Belay Kassa, Rompaey, A., Poesen, J., Bruyssel, S., Deckers, J \& Amare Kassa. 2014. Spatial analysis of land cover changes in eastern Tigray, Ethiopia from 1965 to 2007: Are there signs of a wood transition. Land Degradation and Development, 25(4): 305-318.

Berihun Gebremedhin, Birhane Meressa \& Yirmed Demeke. 2011. Discovery of wintering site of Demoissel Crane in Kafta-Sheraro National Park, Ethiopia. Bulletin of the African Bird Club, 18(2): 199-202.

Binyam Alemu, Efrem Garedew, Zewdu Eshetu \& Habtemariam Kassa. 2015. Land use and land cover changes and associated driving forces in north western lowlands of Ethiopia. International Research Journal of Agricultural Science and Soil Science, 5(1): 28-44.

Campbell, J. 1991. Land or peasants? The dilemma confronting Ethiopia resource conservation. African Affairs, 90: 5-21.

Chen, X. 2002. Using remote sensing and GIS to analyze land cover change and its impacts on regional sustainable development. International Journal of Remote Sensing, 23(1): 107-124. .

CSA (Central Statistical Agency) 2007. Agricultural sample survey report on area and production: Tigray Region, version 1.1. CSA, Addis Ababa, Ethiopia.

Detenbeck, N., Johnston C.A \& Niemi, G. 1993. Wetland effects on lake water quality in the Minneapolis/St. Paul metropolitan area. Landscape Ecology, 8: 39-61.

Diress, T., Stein, R., Moe, P \& Ermias, A. 2010. Land-use/cover dynamics in northern Afar rangelands, Ethiopia. Journal of Agriculture, Ecosystems and Environment, 139: 174-180.

Dompka, V. 1996. Human population, biodiversity and protected areas: Science and policy 
issues. American Association for Advancement of science, Washington, D.C.

Duncan, B.W., Boyle, S., Breininger, D.R \& Schmalzer, P.A. 1999. Coupling past management practice and historic landscape change on John F. Kennedy Space Center, Florida. Landscape Ecology, 37: 124-36.

Efrem Garedew, Sandewall, M., Söderberg, U \& Campbell, B. 2009. Land-use and land-cover dynamics in the central rift valley of Ethiopia. Environmental Management, 44: 683-694.

Endawek Wendim, Gebremeskel Gizaw \& Zenebe Arefine. 2014. Wildlife Conservation Assessment Study on Kafta Shiraro National Park. Report, EWCA, Addis Ababa, 52p (unpubl.).

EWCA (Ethiopian Wildlife Conservation Authority) 2016. Protected areas of Ethiopia. http \|www.ewca.gov (accessed 21 October 2016).

EWNHS (Ethiopian Wildlife and Natural History Society) 2001. Ethiopia. In: L.D.C. Fishpool and M.I. Evans (eds.). Important Bird Areas in Africa and Associated Islands: Priority Sites for Biodiversity Conservation. Bird Life International, Cambridge, pp.291-336.

Eyob Teshome, Randall, R \& Kinahan. A. 2011. The changing face of the Bale Mountains National Park over 32 years: A study of land cover change. Walia-Special Edition on Bale Mountains, 118-130.

FAO. 2005. Global Forest Resource Assessment. FAO Forestry Paper 147. Food and Agriculture Organization of the United Nations, Rome, Italy

FDRE (Federal Democratic Republic of Ethiopia). 2014. Establishment of Kafta-Shraro National Park: Council of Ministers Regulation No. 163/2009. Federal Negarit Gazeta, 26: 4567-4600.

Feoli, E., Vuerich, L.G \& Zerihun Woldu. 2002. Evaluation of environmental degradation in northern Ethiopia using GIS to integrate vegetation, geomorphologic, erosion and socio economic factors. Agriculture, Ecosystems and Environment, 91: 313-325.

Geist, H \& Lambin, E. 2002. Proximate causes and underlying driving forces of tropical deforestation. Biosciences, 52: 143-50.

Geist, H.J. \& Eric, F. L. 2002. Proximate Causes and Underlying Driving Forces of Tropical Deforestation. BioScience, 52(2): 143-150.

Hurni, H. 1988. Degradation and conservation of the resources in the Ethiopian Highlands. Mountain Research and Development, 8: 123-130. 
Jensen, J.R. 1996. Introductory digital image processing: A remote sensing perspective. ISBN: 0-132-05840-5, Prentice Hall.

Kates, R.W., Turner, B.L \& Clark, W.C. 1990. The great transformation, In: B.L. Turner., W.C. Clark., R.W. Kates., J.E. Richards., J. T. Mathews and W.B. Meyer (eds.). The Earth as Transformed by Human Action. Cambridge University Press, Cambridge, pp. 1-17.

KSNP (Kafta-Sheraro National Park). 2016. Biodiversity and Threats to them in the KSNP. KSNP, Humera, Ethiopia.

Lambin, E., Geist, H \& Lepers, E. 2003. Dynamics of land-use and land-cover change in tropical regions. Annual Review Environmental Resource, 28: 205-241.

LEICA Geosystems. 2003. Erdasimagine tour guides. LEICA Geosystems GIS \& Mapping, LLC, Atlanta, Georgia, USA.

Mekbeb Eshetu, Kumara Wakjira \& Minassie Gashaw. 2002. Management plan of Kafta-Sheraro wildlife reserve. Ethiopian Wildlife Conservation Organization, Addis Ababa, Ethiopia.

Mengistu Gebremariam \& Fassil Kibebew. 2010. Land use change effect on soil carbon stock, above ground biomass, aggregate stability and soil crust: a case from Tahtay Adyabo, north-western Tigray, Northern Ethiopia. Journal of the Drylands, 3(2): 220-225.

Messay Mulugeta 2011. Land-use/land-cover dynamics in Nonno district, central Ethiopia. Journal of sustainable development in Africa, 13(1): 1520-5509. .

Millennium Ecosystem Assessment. 2007. A toolkit for understanding and action. Island Press, Washington, DC, pp. 28.

Mulugeta Lemenih, Kassa Habtemariam, Kassie Gebretensae, Abebaw Damtew \& Teka Welday. 2012. Resettlement and woodland management problems and options: a case study from north-western Ethiopia. Land Degradation and Development. http://www.doi: $10.1002 / 1 \mathrm{dr} .2136$

Nagendra, H., Munroe, D \& Southworth, J. 2004. Introduction to the special issue: From pattern to process, landscape fragmentation and the analysis of land-use/land-cover change. Agriculture, Ecosystems and Environment, 101: 111-115.

Skole D.L., Chomentowski, W.H., Salas W.A \& Nobre A.D. 1994. Physical and human dimensions of deforestation in Amazonia. BioScience, 44: 314-322.

Turner, L., Meyer, W \& Skole, D. 1994. Global land-Iceland-cover change. Journal of Remote Sensing, 23: 91-95. 
Vitousek, P. H. 1997. Human domination of earth's ecosystem. Science, 277: 494-499.

World Bank. 2013. World development indicators. The World Bank, http://wdi.worldbank.org/ table/3.2 (accessed 06.01.2017).

Wualem Tadesse, Getachew Desalegn \& Alia, R. 2007. Natural gum and resin bearing species of Ethiopia and their potential applications. Investigación Agraria: Sistemasy Recursos Forestales, 16(3): 211-221

Zerihun Woldu \& Csaplovics, E. 2014. Monitoring land use /land cover dynamics in northwestern Ethiopia using support vector machine earth resources and environmental remote sensing. International Journal of Environmental Studies, 70: 126-139. 